Bollas, H. \& Sierra-García, L. (2021). Assurance on non-financial information in Spain. Contaduría Universidad de Antioquia, 79, 13-37. Doi: https:// doi.org/10.17533/udea.rc.n79a01

\title{
Assurance on non-financial information in Spain
}

Helena María Bollas Araya Universitat Politècnica de València

hebolar@cegea.upv.es

Orcid: 0000000182663622

Laura Sierra-García Universidad Pablo de Olavide

Lnsiegar@upo.es

Orcid: 0000-0001-8880-0683 


\title{
Assurance on non-financial information in Spain
}

Abstract: By means of the Directive 2014/95/EU, the EU established new requirements regarding the disclosure of non-financial information (NFI). The Spanish Act 11/2018 expands these requirements, imposing mandatory external assurance on NFI. This is a pioneering study in Spain, since it was conducted during the first year in which external assurance is mandatory. The aim of this paper is to analyse whether Spanish listed companies fulfil this requirement and to compare assurance practices before the entry into force of the Act and afterwards. Our findings indicate that some companies still fail to adopt external assurance in spite of being mandatory. We found no significant association between the choice of type of assuror and the entry into force of the Act, but this choice depends on some corporate characteristics. On the other hand, we found that the Act implementation and the type of assuror are associated with some assurance features.

Keywords: Non-financial information, Directive 2014/95/EU, Act 11/2018, mandatory assurance, assurors.

\section{Aseguramiento de la información no financiera en España}

Resumen: Mediante la Directiva 2014/95/UE, la UE estableció nuevos requisitos sobre la divulgación de información no financiera (INF). La Ley española 11/2018 amplía estos requisitos, imponiendo la obligatoriedad de la verificación externa de la IFN. Este es un estudio pionero en España, ya que se ha realizado durante el primer año en el que la verificación externa es obligatoria. El objetivo de este trabajo es analizar si las empresas cotizadas españolas cumplen con este requisito y comparar las prácticas de aseguramiento antes y después de la entrada en vigor de la Ley. Nuestros resultados indican que algunas empresas siguen sin adoptar la verificación externa a pesar de ser obligatoria. No encontramos una asociación significativa entre la elección del tipo de asegurador y la entrada en vigor de la Ley, pero esta elección depende de algunas características de la empresa. Por otro lado, encontramos que la aplicación de la Ley y el tipo de asegurador están asociados con algunas características del aseguramiento.

Palabras clave: Información no financiera, Directiva 2014/95/UE, Ley 11/2018, aseguramiento obligatorio, aseguradores.

\begin{abstract}
Asseguramento da informação não financeira na Espanha
Resumo: Mediante a Diretiva 2014/95/UE, a UE estabeleceu novos quesitos sobre a divulgação de informação não financeira (INF). A lei espanhola 11/2018 amplia estas exigências, impondo a obrigatoriedade da verificação externa da INF. Este é um estudo pioneiro na Espanha, dado que tem se realizado durante o primeiro ano no que a verificação externa é obrigatória. O objetivo deste trabalho é analisar se as empresas espanholas listadas cumprem com este requisito e comparar as práticas de asseguramento antes da entrada em vigor da lei e depois. Nossos resultados mostram que algumas empresas seguem sem adotar a verificação externa embora seja obrigatória. Não se encontra uma associação significativa entre a eleição do tipo de assegurador e a entrada em vigor da lei, mas esta eleição depende de algumas características da empresa. Por outro lado, encontramos que a aplicação da lei e o tipo de assegurador estão associados com algumas características da garantia.
\end{abstract}

Palavras chave: Informação não financeira, Diretiva 2014/95/UE, Lei 11/2018, asseguramento obrigatório, asseguradores.

\section{L'Assurance de l'information non financière en Espagne}

Résumé: Par la Directive 2014/95/UE, l'Union Européenne a établi de nouvelles exigences en matière de publication d'informations non financières (INF). La loi espagnole 11/2018 étend ces exigences en imposant une vérification externe obligatoire des INF. Il s'agit d'une étude pionnière en Espagne, car elle a été menée au cours de la première année où la vérification externe est obligatoire. L'objectif de ce document est d'analyser si les entreprises espagnoles cotées en bourse respectent cette exigence, et de comparer les pratiques d'assurance avant et après l'entrée en vigueur de la loi. Nos résultats indiquent que certaines entreprises n'adoptent toujours pas l'assurance externe malgré le fait qu'elle soit obligatoire. Nous ne trouvons pas d'association significative entre le choix du type d'assureur et l'entrée en vigueur de la loi, mais ce choix dépend de certaines caractéristiques de l'entreprise. D'autre part, nous constatons que l'application de la loi et le type d'assureur sont associés à certaines caractéristiques de la garantie. Mots clés: Information non financière, Directive 2014/95/UE, loi 11/2018, assurance obligatoire, assureur. 
Cont. udea (julio-septiembre, pp. 13-37. (C) Universidad de Antioquia-2021.

\title{
Assurance on non-financial information in Spain
}

\author{
Helena María Bollas Araya y Laura Sierra-García \\ https://doi.org/10.17533/udea.rc.n79a01
}

Primera versión recibida en abril de 2021 - Versión aceptada en julio de 2021

\section{Introduction}

The 2014/95/EU Directive, which creates new obligations regarding the disclosure of non-financial information (NFI) and information on diversity (EU, 2014), is perhaps the most important step the European Union has taken to enhance corporate reporting. Under the Directive, Public Interest Entities (PIEs), that is, public and private limited companies with more than 500 employees, must periodically publish a 'non-financial statement' addressing the following areas: environmental and social issues, employment, respect for human rights and measures to combat corruption and bribery. In each of these areas, PIEs should describe the policy pursued, their outcomes (including due diligence processes implemented), the most important sustainability-related risks identified, and key performance indicators. PIEs should provide this information within the management report or within a separate report (for example, on CSR or sustainability), in accordance with international guidelines or standards, such as the UN Guiding Principles on Business and Human Rights, ISO 26000, the OECD Guidelines for Multinational Enterprises, the Global Reporting Initiative or the EU Eco-Management and Audit Scheme.

Under EU rules, the Directive must be transposed into the national legislation of the Member States. Spain did so by Royal Decree-Law 18/2017 of 24 November 2017, which closely mirrored the provisions of the EU Directive and contained no additional requirements (Hernández, 2017). In addition, on 29 December 2018, the Spanish Parliament passed Act 11/2018 (published in the Spanish Official Gazette), which required the provision of new information on non-financial issues and diversity. This Act modified the Code of Commerce, Corporation Law and Audit Law, and introduced important changes in how Spanish companies act. Specifically, it extended the scope of regulatory requirements to all companies with more than 250 employees, imposing mandatory 
external assurance by an independent provider, expanding the content to be reported to include tax payments and issues of diversity related to the wage gap, and requiring companies to disclose NFI online within six months of yearend and to maintain its availability for five years. This Act came into force on 30 December 2018 and therefore affected the data for the fiscal year starting on 1 January 2018, which are reported from the beginning of 2019.

In this paper, we focus on the external assurance requirement. According to KPMG (2020), "assurance of sustainability information has become standard practice for large and mid-cap companies worldwide". The provision of external assurance on the content and structure of sustainability reports enhances their importance, reliability and comparability, and therefore their global credibility (Simnett, 2012). This service is provided by independent experts, termed assurors, who are usually classified as accountants and/or non-accountants. Assurors conduct their activities according to standards such as the AA1000 Assurance Standard (AA1000AS) issued by AccountAbility, and the International Standard of Assurance Engagements Other Than Audits or Reviews of Historical Financial Information (ISAE 3000), published by the IAASB.

The AA1000AS stipulates the requirements for conducting sustainability assurance, that is, to evaluate and provide conclusions on the nature and extent of adherence to the AA1000 AccountAbility Principles of inclusivity (participation of stakeholders), materiality (relevance and significance of an issue) and responsiveness (response to stakeholders), and where applicable the quality of publicly disclosed information on sustainability performance. This standard establishes two levels of assurance: moderate and high (AccountAbility, 2008a, b).

ISAE 3000, on the other hand, sets out principles and procedures for accounting firms to review non-financial information. This standard establishes two levels of assurance, limited and reasonable, and two types of conclusions, unmodified and modified (IAASB, 2013).

The outcome of an assurance process is an assurance statement, the form and content of which differ according to the assuror responsible and the assurance standards applicable (GRI, 2013). According to the AA1000AS and the ISAE 3000, an assurance statement shall include as a minimum the information in Table 1. 
Table 1. Content of an assurance statement

\begin{tabular}{|c|c|}
\hline AA1000AS & ISAE 3000 \\
\hline $\begin{array}{l}\text { - Intended users of the assurance statement. } \\
\text { - The responsibility of the reporting organization } \\
\text { and of the assurance provider. } \\
\text { - Assurance standard/s used, including reference } \\
\text { to the AA1000AS. } \\
\text { - Description of the scope. } \\
\text { - Description of disclosures covered. } \\
\text { - Description of methodology. } \\
\text { - Any limitations. } \\
\text { - Reference to criteria used. } \\
\text { - Statement of level of assurance (moderate or } \\
\text { high). } \\
\text { - Findings and conclusions concerning adherence } \\
\text { to the AA1000 AccountAbility Principles of } \\
\text { Inclusivity, Materiality and Responsiveness (in all } \\
\text { instances). } \\
\text { - Findings and conclusions concerning the } \\
\text { reliability of specified performance information } \\
\text { (for Type } 2 \text { assurance only). } \\
\text { - Observations and/or recommendations. } \\
\text { - Notes on competencies and independence of } \\
\text { the assurance provider. } \\
\text { - Name of the assurance provider. } \\
\text { - Date and place. }\end{array}$ & $\begin{array}{l}\text {-A title clearly indicating that it is an independent } \\
\text { assurance report. } \\
\text { - An addressee. } \\
\text { - An identification or description of the level of } \\
\text { assurance, the subject matter information and, } \\
\text { when appropriate, the underlying subject matter. } \\
\text { - Identification of the applicable criteria. } \\
\text { - Where appropriate, a description of any } \\
\text { significant inherent limitations. } \\
\text { - When the applicable criteria are designed for a } \\
\text { specific purpose, a statement alerting readers. } \\
\text {-A statement to identify the responsible party } \\
\text { and the measurer or evaluator if different, } \\
\text { and to describe their responsibilities and the } \\
\text { practitioner's responsibilities. } \\
\text {-A statement that the engagement was performed } \\
\text { in accordance with this ISAE. } \\
\text {-A statement that the firm of which the } \\
\text { practitioner is a member applies ISQC } 1 \text {, or other } \\
\text { professional requirements. } \\
\text {-A statement that the practitioner complies with } \\
\text { the independence and other ethical requirements } \\
\text { of the IESBA Code, or other professional } \\
\text { requirements. } \\
\text { - An informative summary of the work performed } \\
\text { as the basis for the practitioner's conclusion. } \\
\text { - The practitioner's conclusion. } \\
\text { - The practitioner's signature. } \\
\text { - The date of the assurance report. } \\
\text { - The location in the jurisdiction where the } \\
\text { practitioner practices. }\end{array}$ \\
\hline
\end{tabular}

Source: AccountAbility (2008); IAASB (2013)

This paper examines the issue of mandatory external assurance in the Spanish context. Spain was one of the first countries to establish this obligation and, according to KPMG (2020), is where the independent external assurance of sustainability reporting has increased most strongly. In view of this circumstance, we believe it useful to consider how Spanish listed companies are meeting this requirement.

Our analysis produced the following main findings: firstly, although assurance has been mandatory since the entry into force of Act 11/2018, some companies are still failing to assure their non-financial reports. In addition, certain corporate characteristics influence companies to choose a particular type of 
assuror. Finally, there are significant differences among the assurance standards issued, conclusions drawn and recommendations made.

The rest of this paper is structured as follows. In Section Two, we present the theoretical background considered and review the literature in this field. We then describe the study sample and the analytical method applied. The empirical results are presented in Section 4, and finally we summarise the main conclusions drawn.

\section{Theoretical background and literature review}

Various studies have considered the effects of Directive 2014/95/EU on NFI disclosure among PIEs, in different countries (Venturelli et al., 2017; Manes Rossi et al., 2018; Matuszak and Rozanska, 2017; Sierra Garcia et al., 2018; Mion and Loza, 2019; Tiron-Tudor et al., 2019; Aureli et al., 2020). However, only Venturelli and Pizzi (2020) specifically examined the question of external assurance. By analysing the assurance statements published by a set of European PIEs, these authors found that levels of assurance differed significantly among EU countries, due to the absence of mandatory adoption of specific standards and because of divergences in the transposition of the Directive into national laws.

The assurance process plays an important role in establishing an organisation's legitimacy (O'Dwyer et al., 2011), helping satisfy social demands and thus ensuring the survival of the organisation (Martínez-Ferrero and García-Sánchez, 2018). In Spain, Act 11/2018 made external assurance by an independent provider mandatory. Previous studies of voluntary assurance have concluded that the quality obtained is significantly higher when the assurors are accountants (Romero et al., 2010; Fernández-Feijóo et al., 2012; Zorio et al., 2013), because of their independence and professional expertise (Velte and Stawinoga, 2017). In view of these considerations, we formulated this research question:

RQ1: Did the entry into force of Act 11/2018 influence the type of assuror preferred?

According to Zorio et al. (2013), the business sector in which the organisation operates is a determining factor in the type of assuror chosen. In this respect, Fernández-Feijóo et al. (2015) pointed out that large accounting firms were usually preferred by companies operating in more visible sectors. Similarly, Sierra et al. (2013) observed that companies in sectors such as oil and energy, basic materials or financial services were more likely to choose an accounting firm for this task, while Simnet et al. (2009), Kolk and Perego (2010) and Fernández-Feijóo et al. (2015) all concluded that large companies were more likely to choose accountants than non-accountants as their preferred assurer. Zorio et al. (2013) reported, moreover, that the company's listing status was a significant factor in its choice of assurance provider. In addition, most 
advocates of the upper echelons theory assume, implicitly or explicitly, that CEOs, in almost all organisations, are the most influential parties in this decision-making process (Finkelstein et al., 2009; Lewis et al., 2014). Many recent arguments concerning the crucial role of CEO characteristics in organisations' decision making refer to an earlier notion in strategy research proposed by Chandler (1990), who argued that CEOs play the most critical role in articulating and implementing a firm's strategies. Reflecting these concerns, our second research question inquires:

RQ2: Is the choice of the type of assuror associated with particular corporate characteristics?

Institutional theory explains that organisations may adopt similar practices or structures in order to conform to external expectations and to gain legitimacy and support (Deegan, 2002; DiMaggio and Powell, 1983), doing so via mimetic, coercive and normative isomorphism. Mimetic isomorphism is the process by which organisations emulate the structures and procedures adopted by others. Coercive isomorphism takes place when external factors (e.g., government policy, regulation or commercial pressures) persuade or oblige organisations to adopt specific internal structures and procedures. Finally, normative isomorphism is the process by which organisations adopt the structures and procedures recommended or required by dominant professions, professional bodies and/or consultants (DiMaggio and Powell, 1983). According to Adams and Narayanan (2007), normative isomorphism is consistent with the 'standardisation' of assurance through the adoption of standards (Smith et al. 2011), such as ISAE 3000 and AA1000AS. Research has shown that most assurors use ISAE 3000 (Manetti and Becatti, 2009; Fonseca, 2010; Ferreira et al., 2015; Seguí et al., 2018). However, other assurors apply a combination of standards (Manetti and Toccafondi, 2012; Perego and Kolk, 2012). Meanwhile, O'Dwyer and Owen (2005) and Deegan et al. (2006a) noted that in many cases no mention is made of standards. O'Dwyer and Owen (2005) commented that non-accountant assurors are more likely than accountants to mention standards, especially AA1000AS. In contrast, Deegan et al. (2006a, b), Mock et al. $(2007,2013)$ and Bollas-Araya et al. (2018) affirm that accountants are more likely to mention standards. In this respect, too, Perego and Kolk (2012), Manetti and Toccafondi (2012), Bollas-Araya et al. (2018) and Seguí et al. (2018) state that accountants are more likely to employ ISAE 3000, whereas non-accountants tend to prefer AA1000AS. Finally, Manetti and Toccafondi (2012) and Seguí et al. (2018) observe that accountants are also more likely to combine different standards in their assurance procedures. Taking these considerations into account, we formulated the following research questions:

RQ3.1: Is the application of Act 11/2018 associated with the use of assurance standards? 
RQ3.2: Is the type of assuror associated with the use of assurance standards?

According to legitimacy theory, the scope and intensity of the assurance processes performed by an independent third party essentially determine the reliability of institutional reports. Therefore, organisations should seek a reasonable/high level of assurance in order to maximise the credibility and value of their reports (Velte and Stawinoga, 2017). Nevertheless, studies have shown that most assurors only certify a limited/moderate level of assurance (Hasan et al., 2005; Manetti and Becatti, 2009; Manetti and Toccafondi, 2012; Seguí et al., 2018). In this respect, O'Dwyer and Owen (2005) and Bollas-Araya et al. (2018) found that accountants are more likely to indicate the level of assurance and to apply a more conservative, cautious and limited approach, thus offering low levels of assurance, whereas non-accountants apply a more evaluative approach and offer higher levels. The view that large accounting firms are more likely to provide lower levels of assurance was corroborated by Mock et al. $(2007,2013)$ and Martínez-Ferrero and García-Sánchez (2018). In this respect, we address the following research questions:

RQ4.1: Is the application of Act 11/2018 associated with the level of assurance applied?

RQ4.2: Is the type of assuror employed associated with the level of assurance supplied?

In their study, Perego and Kolk (2012) concluded that the quality of the recommendations and opinions provided is positively associated with the involvement of non-accountants as assurors. On the other hand, Martínez-Ferrero and García-Sánchez (2018) showed that the greater experience of the Big 4 firms and their specialist skills and training increased the probability of the opinions offered being more precise. However, Mock et al. $(2007,2013)$ found that large accounting firms were less likely to include recommendations in their assurance statements. While Manetti and Toccafondi (2012) evidenced that consultants more commonly indicated possible areas of improvement, Bollas-Araya et al. (2018) found no association between the inclusion of recommendations and the type of assuror involved. In view of these conflicting findings, we formulated the following research questions:

RQ5.1: Is the application of Act 11/2018 associated with the type of conclusions drawn?

RQ5.2: Is the type of assuror provider associated with the type of conclusions drawn?

RQ6.1: Is the application of Act 11/2018 associated with the recommendations made?

RQ6.2: Is the type of assuror associated with the recommendations made? 


\section{Methods}

\section{III.1 Sample description}

This paper analyses Spanish companies' compliance with the requirements of Act 11/2018, derived from Directive 2014/95/EU, with respect to mandatory assurance on non-financial reporting. In particular, we focus on the companies listed on the IBEX 35 index of the Madrid Stock Exchange in June 2018 and June 2019. As shown in Table 2, the initial observation identified 130 companies, but those which were foreign based were excluded from the analysis. Thus, Samples 1 and 2 were composed of 124 and 127 companies, respectively. We then determined which companies issued non-financial reports, locating 104 companies in the first period and 101 in the second. Finally, we considered which nonfinancial reports were assured by an independent provider, and found 40 and 85 reports in the first and second periods, respectively.

Table 2. Sample Description

\begin{tabular}{lcc}
\hline & $\begin{array}{c}\text { Sample 1 } \\
\text { (June 2018) }\end{array}$ & $\begin{array}{c}\text { Sample 2 } \\
\text { (June 2019) }\end{array}$ \\
\hline Madrid Stock Exchange (IBEX 35) & 130 & 130 \\
Less foreign companies & 124 & 127 \\
Companies with non-financial report & 104 & 101 \\
Non-financial reports with assurance & 40 & 85 \\
\hline
\end{tabular}

Table 3 shows that, of the companies that assured their non-financial reports, most operated in the basic materials, industry and construction sector $(31.2 \%)$, while the smallest group corresponded to the petroleum and energy sector $(9.6 \%)$. Although in both study periods assurance was more frequently employed among companies in the basic materials, industry and construction sector, the proportion of reports assured decreased from $35 \%$ to $29.4 \%$ between the first and second periods. Before Act 11/2018 came into force, assurance was least frequently employed among companies in the consumer goods sector (5\%), but by the second study period this proportion had risen to $18.8 \%$. After the legislation came into force, assurance was least common among companies in the petroleum and energy sector (7.1\%).

Table 3. Assurance by sector

\begin{tabular}{lcccccc}
\hline & \multicolumn{2}{c}{ Pre-Act } & \multicolumn{2}{c}{ Post-Act } & \multicolumn{2}{c}{ Total } \\
\hline Sector & $\mathrm{n}$ & $\%$ & $\mathrm{n}$ & $\%$ & $\mathrm{n}$ & $\%$ \\
Consumer goods & 2 & 5.0 & 16 & 18.8 & 18 & 14.4 \\
Basic materials, industry and construction & 14 & 35.0 & 25 & 29.4 & 39 & 31.2
\end{tabular}


Assurance on non-financial information in Spain

\begin{tabular}{lcccccc}
\hline & \multicolumn{2}{c}{ Pre-Act } & \multicolumn{2}{c}{ Post-Act } & \multicolumn{2}{c}{ Total } \\
\hline Petroleum and energy & 6 & 15.0 & 6 & 7.1 & 12 & 9.6 \\
Consumer services & 4 & 10.0 & 15 & 17.6 & 19 & 15.2 \\
Financial services and real estate & 9 & 22.5 & 14 & 16.5 & 23 & 18.4 \\
Technology and telecommunications & 5 & 12.5 & 9 & 10.6 & 14 & 11.2 \\
Total & 40 & 100.0 & 85 & 100.0 & 125 & 100.0 \\
\hline
\end{tabular}

\section{III.2 Analytical methods and study variables}

The research questions were addressed using descriptive statistics and multilogistic regression. Specifically, cross-tabulation analysis and chi-square tests were applied to determine whether the entry into force of Act 11/2018 influenced the selection of the type of assuror. In addition, the following model was formulated to describe the corporate factors that influenced the choice of type of assuror:

Type of Assuror $=\alpha+\beta_{1}$ Sustainability Committee $+\beta_{2}$ CEO Tenure $+\beta_{3}$ CEO Gender $+\beta_{4}$ Sensitive sector $+\beta_{5}$ Period $+\beta_{6}$ Index $+\beta_{7}$ Size $+\beta_{8}$ Leverage $+\beta_{9}$ ROA $+\beta_{8}$ Loss $+\varepsilon$

Cross-tabulation analysis and chi-square tests were also used to verify whether the entry into force of Act 11/2018 and the type of assuror employed impacted on certain characteristics of the assurance report, such as standards, levels, conclusions and recommendations.

In line with the study model and research questions established, the following variables were included in the analysis (see Table 4).

Table 4. Study variables

\begin{tabular}{|c|c|}
\hline Variable & Definition \\
\hline ASSURANCE & $\begin{array}{l}\text { A dichotomous variable that takes the value ' } 1 \text { ' if the company assured its non- } \\
\text { financial report and ' } 0 \text { ' otherwise. }\end{array}$ \\
\hline TYPE OF ASSUROR & $\begin{array}{l}\text { A categorical variable that takes the value ' } 0 \text { ' if the assuror was Ernst \& Young, } \\
\text { ' } 1 \text { ' if it was Deloitte, ' } 2 \text { ' if it was KPMG, ' } 3 \text { ' if it was PwC and ' } 4 \text { ' if it was a non- } \\
\text { Big } 4 \text { firm. }\end{array}$ \\
\hline PERIOD & $\begin{array}{l}\text { A categorical variable that takes the value ' } 1 \text { ' after the entry into force of Act } \\
11 / 2018 \text { and ' } 0 \text { ' before this date. }\end{array}$ \\
\hline $\begin{array}{l}\text { SUSTAINABILITY } \\
\text { COMMITTEE }\end{array}$ & $\begin{array}{l}\text { A dichotomous variable that takes the value ' } 1 \text { ' if the company had a sustainability } \\
\text { committee or similar and ' } 0 \text { ' otherwise. }\end{array}$ \\
\hline CEO TENURE & Experience (years) of the CEO in this position. \\
\hline CEO GENDER & $\begin{array}{l}\text { A categorical variable that takes the value ' } 1 \text { ' if the CEO was female and ' } 0 \text { ' if } \\
\text { the CEO was male. }\end{array}$ \\
\hline SENSITIVE SECTOR & $\begin{array}{l}\text { A dichotomous variable that takes the value ' } 1 \text { ' for sensitive sectors and ' } 0 \text { ' } \\
\text { otherwise. }\end{array}$ \\
\hline
\end{tabular}




\begin{tabular}{|c|c|}
\hline Variable & Definition \\
\hline INDEX & $\begin{array}{l}\text { A dichotomous variable that takes the value ' } 1 \text { ' if the company was listed on the } \\
\text { IBEX-35 index and ' } 0 \text { ' otherwise. }\end{array}$ \\
\hline SIZE & Natural log of total assets. \\
\hline LEVERAGE & Total debt divided by equity. \\
\hline ROA & Profit divided by total assets. \\
\hline LOSSES & $\begin{array}{l}\text { A dichotomous variable that takes the value ' } 1 \text { ' if the company made financial } \\
\text { losses during the previous year and ' } 0 \text { ' otherwise. }\end{array}$ \\
\hline STANDARDS & $\begin{array}{l}\text { A dichotomous variable that takes the value ' } 1 \text { ' if the assurors mentioned the } \\
\text { standards used in the assurance process and ' } 0 \text { ' otherwise. }\end{array}$ \\
\hline ISAE $3000+$ AA100AS & $\begin{array}{l}\text { A dichotomous variable that takes the value ' } 1 \text { ' if the assurors used both the } \\
\text { ISAE } 3000 \text { and the AA1000AS standards and ' } 0 \text { ' otherwise. }\end{array}$ \\
\hline ISAE3000 & $\begin{array}{l}\text { A dichotomous variable that takes the value ' } 1 \text { ' if the assurors used the ISAE } \\
3000 \text { standard and ' } 0 \text { ' otherwise. }\end{array}$ \\
\hline AA1000AS & $\begin{array}{l}\text { A dichotomous variable that takes the value ' } 1 \text { ' if the assurors used the } \\
\text { AA1000AS standard and ' } 0 \text { ' otherwise. }\end{array}$ \\
\hline LEVEL_1 & $\begin{array}{l}\text { A dichotomous variable that takes the value ' } 1 \text { ' if the assuror mentioned the } \\
\text { level of assurance provided and ' } 0 \text { ' otherwise. }\end{array}$ \\
\hline LEVEL_2 & $\begin{array}{l}\text { A categorical variable that takes the value ' } 0 \text { ' if the level of assurance provided } \\
\text { was limited/moderate and ' } 1 \text { ' when it was reasonable/high, or a combination of } \\
\text { the two levels. }\end{array}$ \\
\hline CONCLUSION & $\begin{array}{l}\text { A categorical variable that takes the value ' } 0 \text { ' if the conclusions were unmodified } \\
\text { and ' } 1 \text { ' otherwise. }\end{array}$ \\
\hline RECOMMENDATIONS & $\begin{array}{l}\text { A dichotomous variable that takes the value ' } 1 \text { ' if the assuror made } \\
\text { recommendations and ' } 0 \text { ' otherwise. }\end{array}$ \\
\hline
\end{tabular}

Note: Sensitive sectors include petroleum and energy, financial services and real estate, and technology and telecommunications. According to prior research (Simnett et al., 2009; Kolk and Perego, 2010), these sectors are likely to have specific information policies about their behaviour with respect to corporate social responsibility.

\section{Results}

Table 5 shows the descriptive statistics obtained for the dummy variables. The following main features can be observed. Before Act 11/2018 came into force, $32 \%$ of reports were assured, a value that had risen to $68 \%$ one year later. Some companies are still failing to assure their non-financial report despite this now being mandatory. Most companies employ accountants to assure their nonfinancial reports $(90.4 \%)$, and this sector is mainly composed of the Big 4 firms (88\%). In 2019 , only $24.8 \%$ of companies had a sustainability committee. The CEO was male in $97.6 \%$ of the companies considered. By business sector, $39.2 \%$ of the companies operated in a 'sensitive' area. $49.6 \%$ of the companies were IBEX-35 listed. Only $12.8 \%$ of the companies made a financial loss during the previous twelve months. $96 \%$ of assurors identified the standards used, which in most cases was the combination of ISAE 3000 and AA1000AS (83.3\%); 96\% of assurors mentioned the level of assurance provided, which in most cases was 
Assurance on non-financial information in Spain

limited/moderate $(94.2 \%)$; $90.4 \%$ of the conclusions drawn were unmodified, and only $20.8 \%$ of the assurors made recommendations.

Table 5. Descriptive statistics: dummy variables

\begin{tabular}{|c|c|c|c|}
\hline Variables & $\mathbf{n}$ & $\%$ & Cum. \\
\hline \multicolumn{4}{|l|}{ PERIOD } \\
\hline Pre-Act & 40 & 32.0 & 32.0 \\
\hline Post-Act & 85 & 68.0 & 100.0 \\
\hline \multicolumn{4}{|l|}{ TYPE OF ASSUROR } \\
\hline Non-accountants & 12 & 9.6 & 100.0 \\
\hline \multicolumn{4}{|l|}{ Accountants } \\
\hline EY & 22 & 17.6 & 17.6 \\
\hline Deloitte & 25 & 20.0 & 37.6 \\
\hline KPMG & 29 & 23.2 & 60.8 \\
\hline $\mathrm{PwC}$ & 34 & 27.2 & 88.0 \\
\hline Others & 3 & 2.4 & 90.4 \\
\hline \multicolumn{4}{|l|}{ SUSTAINABILITY COMMITTEE } \\
\hline No & 94 & 75.2 & 75.2 \\
\hline Yes & 31 & 24.8 & 100.0 \\
\hline \multicolumn{4}{|l|}{ CEO GENDER } \\
\hline Male & 122 & 97.6 & 97.6 \\
\hline Female & 3 & 2.4 & 100.0 \\
\hline \multicolumn{4}{|l|}{ SENSITIVE SECTOR } \\
\hline No & 76 & 60.8 & 60.8 \\
\hline Yes & 49 & 39.2 & 100.0 \\
\hline \multicolumn{4}{|l|}{ INDEX } \\
\hline Not included & 63 & 50.4 & 50.4 \\
\hline Included & 62 & 49.6 & 100.0 \\
\hline \multicolumn{4}{|l|}{ LOSSES } \\
\hline No & 109 & 87.2 & 87.2 \\
\hline Yes & 16 & 12.8 & 100.0 \\
\hline \multicolumn{4}{|l|}{ STANDARDS } \\
\hline Not mentioned & 5 & 4.0 & 4.0 \\
\hline \multicolumn{4}{|l|}{ Mentioned } \\
\hline Only ISAE 3000 & 18 & 15.0 & 15.0 \\
\hline ISAE $3000+$ AA1000AS & 100 & 83.3 & 98.3 \\
\hline Other & 2 & 1.7 & 100.0 \\
\hline \multicolumn{4}{|l|}{ LEVEL } \\
\hline Not mentioned & 5 & 4.0 & 4.0 \\
\hline \multicolumn{4}{|l|}{ Mentioned } \\
\hline Limited/moderate & 113 & 94.2 & 94.2 \\
\hline Reasonable/high or combination & 7 & 5.8 & 100.0 \\
\hline
\end{tabular}




\begin{tabular}{lccc}
\hline \multicolumn{1}{c}{ Variables } & n & \% & Cum. \\
\hline CONCLUSIONS & & & \\
\hline Unmodified & 113 & 90.4 & 90.4 \\
Modified & 12 & 9.6 & 100.0 \\
\hline RECOMMENDATIONS & & & \\
\hline No & 99 & 79.2 & 79.2 \\
Yes & 26 & 20.8 & 100.0 \\
\hline TOTAL & 125 & 100.0 & \\
\hline
\end{tabular}

Table 6 shows the descriptive statistics for the continuous variables. The average company size (natural logarithm of total assets) was 15.66 . The mean leverage was .717 and individual values ranged from .21 to 2.10 . Finally, the average ROA was $4.5 \%$, ranging from a minimum value of $-41 \%$ to a maximum of $85 \%$.

Table 6. Descriptive statistics: continuous variables

\begin{tabular}{lccccc}
\hline \multicolumn{1}{c}{ Variables } & Obs. & Mean & Std. Dev. & Min & Max \\
\hline CEO TENURE & 125 & 7.704 & 7.136937 & 0 & 32 \\
SIZE & 125 & 15.65793 & 2.147742 & 10.93007 & 21.1012 \\
LEVERAGE & 125 & .7167435 & .2507664 & .213071 & 2.10999 \\
ROA & 125 & .045744 & .1105386 & -.4102509 & .8499616 \\
\hline
\end{tabular}

The results shown in Table 7 show that the proportion of accountants vs. non-accountants providing external assurance fell after Act 11/2018 came into force (from $92.5 \%$ to $89.4 \%$ ). Nevertheless, this change was not statistically significant, and at both time points a large majority of companies hired accountants to perform this task.

Table 7. Chi-square test: type of assuror per period

\begin{tabular}{lccccccc}
\hline \multicolumn{1}{c}{ Type of assuror } \\
\hline \multicolumn{1}{c}{ Non-accountant } & Accountant & \multicolumn{2}{c}{ Total } \\
\hline Period & $\mathbf{n}$ & $\%$ & $\mathbf{n}$ & $\%$ & $\mathbf{n}$ & $\%$ \\
\hline Before Act 11/2018 & 3 & 7.5 & 37 & 92.5 & 40 & 100.0 \\
After Act 11/2018 & 9 & 10.6 & 76 & 89.4 & 85 & 100.0 \\
Total & 12 & 9.6 & 113 & 90.4 & 125 & 100.0 \\
\hline Pearson chi-square $=0.299(\mathrm{p}=0.585)$ & & & & \\
Fisher's exact test $=0.425(\mathrm{p}=0.750)$ \\
\hline
\end{tabular}


As detailed in Table 8, certain corporate factors influence the choice of type of assuror, as regards Big 4 vs. non-Big 4 firms. Specifically, companies listed in the IBEX-35 were more likely to choose one of the Big 4 firms to provide assurance on their non-financial reports $(\mathrm{p}<0.05)$. Companies that made a financial loss during the previous year tended to prefer EY $(p<0.01)$, companies operating in a non-sensitive business sector were more likely to select KPMG $(\mathrm{p}<0.05)$, and those with a sustainability committee $(\mathrm{p}<0.05)$ and/or whose CEO had lengthy experience in this role $(\mathrm{p}<0.05)$ were more inclined to opt for PwC. The results obtained show that the model obtains a good fit, with Prob $>$ chi $^{2}$ significant $(\mathrm{p}<0.01)$ and pseudo $\mathrm{R}^{2}=0.1727$.

Table 8. Multi-logistic regression: choice of type of assuror

\begin{tabular}{lccc}
\hline \multicolumn{1}{c}{ ASSUROR } & Coef. & Std. Err. & P $>\mathbf{z}$ \\
\hline SUSTAINABILITY COMMITTEE & 1.935672 & $(1.23202)$ & 0.116 \\
CEO TENURE & -.0137768 & $(.0599415)$ & 0.818 \\
CEO GENDER & -.5496239 & $(2268.535)$ & 1.000 \\
SENSITIVE SECTOR & -.2504062 & $(.3007044)$ & 0.405 \\
PERIOD & -2.483784 & $(1.821648)$ & 0.173 \\
INDEX & 17.02609 & 6.940296 & $0.014^{*}$ \\
SIZE & -2.405108 & 1.546988 & 0.120 \\
LEVERAGE & -.8427132 & .9127529 & 0.356 \\
ROA & .0171374 & .9408851 & 0.985 \\
LOSSES & 4.286936 & 1.437955 & $0.003 \%$ \\
\hline Deloitte & & & \\
\hline SUSTAINABILITY COMMITTEE & 1.086673 & 1.234794 & 0.379 \\
CEO TENURE & -.0052732 & .0536349 & 0.922 \\
CEO GENDER & 13.70019 & 1346.7 & 0.992 \\
SENSITIVE SECTOR & .1493881 & .8294164 & 0.857 \\
PERIOD & .2562847 & .9101325 & 0.778 \\
INDEX & 2.755072 & 1.367569 & $0.044^{*}$ \\
SIZE & -.0269819 & .2730729 & 0.921 \\
LEVERAGE & -1.456153 & 1.599515 & 0.363 \\
ROA & .2468696 & 4.401268 & 0.955 \\
LOSSES & .2453861 & 1.174972 & 0.835 \\
\hline & & &
\end{tabular}




\begin{tabular}{|c|c|c|c|}
\hline ASSUROR & Coef. & Std. Err. & $\mathrm{P}>\mathrm{z}$ \\
\hline \multicolumn{4}{|l|}{ KPMG } \\
\hline SUSTAINABILITY COMMITTEE & .8830903 & 1.197703 & 0.461 \\
\hline CEO TENURE & .0163623 & .0487227 & 0.737 \\
\hline CEO GENDER & .4805009 & 2089.544 & 1.000 \\
\hline SENSITIVE SECTOR & -1.918706 & .9213121 & $0.037^{*}$ \\
\hline PERIOD & .4005886 & .90138 & 0.657 \\
\hline INDEX & 3.046756 & 1.350631 & $0.024^{*}$ \\
\hline SIZE & .1533872 & .2763351 & 0.579 \\
\hline LEVERAGE & .7691088 & 1.403096 & 0.584 \\
\hline ROA & .6782995 & 2.812949 & 0.809 \\
\hline LOSSES & -.8117533 & 1.206361 & 0.501 \\
\hline \multicolumn{4}{|l|}{$\mathrm{PwC}$} \\
\hline SUSTAINABILITY COMMITTEE & 1.992954 & 1.170823 & $0.089 \%$ \\
\hline CEO TENURE & .0992249 & .0488421 & $0.042^{*}$ \\
\hline CEO GENDER & 14.83224 & 1346.701 & 0.991 \\
\hline SENSITIVE SECTOR & -.1094981 & .8772217 & 0.901 \\
\hline PERIOD & .2520593 & .8970768 & 0.779 \\
\hline INDEX & 2.863524 & 1.363148 & $0.036 *$ \\
\hline SIZE & .09232 & .2814459 & 0.743 \\
\hline LEVERAGE & .4188503 & 1.735027 & 0.809 \\
\hline ROA & -2.651104 & 5.372065 & 0.622 \\
\hline LOSSES & -1.200503 & 1.41946 & 0.398 \\
\hline $\begin{array}{l}\text { Number of obs. }=125 \\
\text { LR chi }{ }^{2}(40)=67.99 \\
\text { Prob }>\text { chi }^{2}=0.0038 \\
\text { Pseudo } R^{2}=0.1727 \\
\text { Log likelihood }=-162.89927\end{array}$ & & & \\
\hline
\end{tabular}

Note: Non-Big 4 firms are taken as the base

As concerns compliance or otherwise with the ISAE 3000 and AA1000AS assurance standards, Table 9 shows that no association was found between the entry into force of Act 11/2018 and reference to one or other of these standards in the assurance report $(\mathrm{p}>0.10)$. In both study periods, most assurors identify the standards complied with in performing the assurance task. On the other hand, there was a statistically significant association between the joint use of the two standards and the entry into force of the Act $(\mathrm{p}<0.01)$. The likelihood of ISAE 3000 and AA1000AS being jointly used was greater after the Act became law $(89.2 \%)$ than before $(70.3 \%)$. We also tested the application of each 
standard separately, and found that the use of ISAE 3000 was not significantly associated with the implementation of the Act ( $\mathrm{p}>0.10)$. Thus, in both study periods, most assurors followed this standard. In contrast, the use of AA1000AS was significantly associated with the Act's entry into force $(\mathrm{p}<0.05)$. Thus, the likelihood of the assuror following this standard was higher before than after this event (35.1\% vs. $15.7 \%$, respectively).

Table 9. Chi-square test: Use of assurance standards before and after Act 11/2018

\begin{tabular}{|c|c|c|c|c|c|c|}
\hline \multicolumn{7}{|c|}{ Assurance standards } \\
\hline Standards & \multicolumn{2}{|c|}{ Not mentioned } & \multicolumn{2}{|c|}{ Mentioned } & \multicolumn{2}{|c|}{ Total } \\
\hline Period & $\mathrm{n}$ & $\%$ & $\mathrm{n}$ & $\%$ & $\mathrm{n}$ & $\%$ \\
\hline Before Act 11/2018 & 3 & 7.5 & 37 & 92.5 & 40 & 100.0 \\
\hline After Act 11/2018 & 2 & 2.4 & 83 & 97.6 & 85 & 100.0 \\
\hline Total & 5 & 4.0 & 120 & 96.0 & 125 & 100.0 \\
\hline \multicolumn{7}{|c|}{$\begin{array}{l}\text { Pearson chi-square }=1.877(\mathrm{p}=0.171) \\
\text { Fisher's exact test }(\mathrm{p}=0.326 ; 0.186)\end{array}$} \\
\hline ISAE $3000+$ AA1000AS & \multicolumn{2}{|c|}{ No } & \multicolumn{2}{|c|}{ Yes } & \multicolumn{2}{|c|}{ Total } \\
\hline Period & $\mathrm{n}$ & $\%$ & $\mathrm{n}$ & $\%$ & $\mathrm{n}$ & $\%$ \\
\hline Before Act $11 / 2018$ & 11 & 29.7 & 26 & 70.3 & 37 & 100.0 \\
\hline After Act 11/2018 & 9 & 10.8 & 74 & 89.2 & 83 & 100.0 \\
\hline Total & 20 & 16.7 & 100 & 83.3 & 120 & 100.0 \\
\hline \multicolumn{7}{|c|}{ Pearson chi-square $=6.572(\mathrm{p}=0.010)$} \\
\hline ISAE 3000 & \multicolumn{2}{|c|}{ No } & \multicolumn{2}{|c|}{ Yes } & \multicolumn{2}{|c|}{ Total } \\
\hline Period & $\mathrm{n}$ & $\%$ & $\mathrm{n}$ & $\%$ & $\mathrm{n}$ & $\%$ \\
\hline Before Act $11 / 2018$ & 0 & 0.0 & 37 & 100.0 & 37 & 100.0 \\
\hline After Act 11/2018 & 2 & 2.4 & 81 & 97.6 & 83 & 100.0 \\
\hline Total & 2 & 1.7 & 118 & 98.3 & 120 & 100.0 \\
\hline \multicolumn{7}{|c|}{$\begin{array}{l}\text { Pearson chi-square }=0.907(\mathrm{p}=0.341) \\
\text { Fisher's exact test }(\mathrm{p}=1.000 ; 0.477)\end{array}$} \\
\hline AA1000AS & \multicolumn{2}{|c|}{ No } & \multicolumn{2}{|c|}{ Yes } & \multicolumn{2}{|c|}{ Total } \\
\hline Period & $\mathrm{n}$ & $\%$ & $\mathrm{n}$ & $\%$ & $\mathrm{n}$ & $\%$ \\
\hline Before Act $11 / 2018$ & 24 & 64.9 & 13 & 35.1 & 37 & 100.0 \\
\hline After Act 11/2018 & 70 & 84.3 & 13 & 15.7 & 83 & 100.0 \\
\hline Total & 94 & 78.3 & 26 & 21.7 & 120 & 100.0 \\
\hline Pearson chi-square $=5{ }^{\prime}$ & & & & & & \\
\hline
\end{tabular}

Analysis of the application of standards by type of assuror (Table 10) shows that only accountants mentioned the standards before the Act's implementation. Specifically, 70.3\% combined the two standards (ISAE 3000 and AA1000AS), all 
of them complied with ISAE 3000 and $35.1 \%$ also followed AA1000AS. After the Act came into force, all assurance reports prepared by accountants referred to the standards, whereas non-accountants alluded to them in only $77.8 \%$ of cases. The vast majority of accountants $(96.1 \%)$ combined the two standards, while only $14.3 \%$ of non-accountants did so. All of the accountant firms used ISAE 3000, as did $71.4 \%$ of the non-accountants. With respect to AA1000AS, $11.8 \%$ of accountants adhered to this standard, while none of the non-accountants did so. In both study periods (before and after the implementation of Act 11/2018) there is a significant association between the type of assuror and reference to the standard(s) used ( $p<0.01$ ). After implementation of the Act, the use of the two standards in combination, or that of ISAE 3000 alone, was also significantly associated with the type of assuror $(\mathrm{p}<0.01)$. Accountants were more likely to mention standards, to combine standards and to use ISAE 3000.

Table 10. Chi-square test: Assurance standards by type of assuror

\begin{tabular}{|c|c|c|c|c|c|c|c|c|c|c|c|c|}
\hline \multicolumn{13}{|c|}{ Assurance standards } \\
\hline \multirow{3}{*}{$\begin{array}{l}\text { Standards } \\
\text { Assuror }\end{array}$} & \multicolumn{6}{|c|}{ Before the Act } & \multicolumn{6}{|c|}{ After the Act } \\
\hline & \multicolumn{2}{|c|}{$\begin{array}{c}\text { Not } \\
\text { mentioned }\end{array}$} & \multicolumn{2}{|c|}{ Mentioned } & \multicolumn{2}{|c|}{ Total } & \multicolumn{2}{|c|}{$\begin{array}{c}\text { Not } \\
\text { mentioned }\end{array}$} & \multicolumn{2}{|c|}{ Mentioned } & \multicolumn{2}{|c|}{ Total } \\
\hline & $\mathrm{n}$ & $\%$ & $\mathrm{n}$ & $\%$ & $\mathrm{n}$ & $\%$ & $\mathrm{n}$ & $\%$ & $\mathrm{n}$ & $\%$ & $\mathrm{n}$ & $\%$ \\
\hline Non-accountant & 3 & 100.0 & 0 & 0.00 & 3 & 100.0 & 2 & 22.2 & 7 & 77.8 & 9 & 100.0 \\
\hline Accountant & 0 & 0.0 & 37 & 100.0 & 37 & 100.0 & 0 & 0.0 & 76 & 100.0 & 76 & 100.0 \\
\hline \multirow[t]{2}{*}{ Total } & 3 & 7.5 & 37 & 92.5 & 40 & 100.0 & 2 & 2.4 & 83 & 97.6 & 85 & 100.0 \\
\hline & \multicolumn{6}{|c|}{$\begin{array}{l}\text { Pearson chi-square }=40.000(\mathrm{p}=0.000) \\
\text { Fisher's exact test }(\mathrm{p}=0.000 ; 0.000)\end{array}$} & \multicolumn{6}{|c|}{$\begin{array}{l}\text { Pearson chi-square }=17.226(\mathrm{p}=0.000) \\
\text { Fisher's exact test }(\mathrm{p}=0.010 ; 0.010)\end{array}$} \\
\hline $\begin{array}{l}\text { ISAE } 3000+ \\
\text { AA1000AS }\end{array}$ & \multicolumn{2}{|c|}{ No } & \multicolumn{2}{|c|}{ Yes } & \multicolumn{2}{|c|}{ Total } & \multicolumn{2}{|c|}{ No } & \multicolumn{2}{|c|}{ Yes } & \multicolumn{2}{|c|}{ Total } \\
\hline Assuror & $\mathrm{n}$ & $\%$ & $\mathrm{n}$ & $\%$ & $\mathrm{n}$ & $\%$ & $\mathrm{n}$ & $\%$ & $\mathrm{n}$ & $\%$ & $\mathrm{n}$ & $\%$ \\
\hline Non-accountant & 0 & 0.0 & 0 & 0.0 & 0 & 0.0 & 6 & 85.7 & 1 & 14.3 & 7 & 100.0 \\
\hline Accountant & 11 & 29.7 & 26 & 70.3 & 37 & 100.0 & 3 & 3.9 & 73 & 96.1 & 76 & 100.0 \\
\hline \multirow[t]{2}{*}{ Total } & 11 & 29.7 & 26 & 70.3 & 37 & 100.0 & 9 & 10.8 & 74 & 89.2 & 83 & 100.0 \\
\hline & \multicolumn{6}{|c|}{$\begin{array}{l}\text { No statistics are computed because } \\
\text { ASSUROR is a constant. }\end{array}$} & \multicolumn{6}{|c|}{$\begin{array}{l}\text { Pearson chi-square }=44.327(\mathrm{p}=0.000) \\
\text { Fisher's exact test }(\mathrm{p}=0.000 ; 0.000)\end{array}$} \\
\hline ISAE 3000 & \multicolumn{2}{|c|}{ No } & \multicolumn{2}{|r|}{ Yes } & \multicolumn{2}{|c|}{ Total } & \multicolumn{2}{|c|}{ No } & \multicolumn{2}{|c|}{ Yes } & \multicolumn{2}{|c|}{ Total } \\
\hline Assuror & $\mathrm{n}$ & $\%$ & $\mathrm{n}$ & $\%$ & $\mathrm{n}$ & $\%$ & $\mathrm{n}$ & $\%$ & $\mathrm{n}$ & $\%$ & $\mathrm{n}$ & $\%$ \\
\hline Non-accountant & 0 & 0.0 & 0 & 0.0 & 0 & 0.0 & 2 & 28.6 & 5 & 71.4 & 7 & 100.0 \\
\hline Accountant & 0 & 0.0 & 37 & 100.0 & 37 & 100.0 & 0 & 0.0 & 76 & 100.0 & 76 & 100.0 \\
\hline Total & 0 & 0.0 & 37 & 100.0 & 37 & 100.0 & 2 & 2.4 & 81 & 97.6 & 83 & 100.0 \\
\hline
\end{tabular}


Assurance on non-financial information in Spain

\begin{tabular}{|c|c|c|c|c|c|c|c|c|c|c|c|c|}
\hline \multicolumn{13}{|c|}{ Assurance standards } \\
\hline \multirow[b]{2}{*}{ Standards } & \multicolumn{6}{|c|}{ Before the Act } & \multicolumn{6}{|c|}{ After the Act } \\
\hline & \multicolumn{2}{|c|}{$\begin{array}{c}\text { Not } \\
\text { mentioned }\end{array}$} & \multicolumn{3}{|c|}{ Mentioned } & Total & \multicolumn{2}{|c|}{$\begin{array}{c}\text { Not } \\
\text { mentioned }\end{array}$} & \multicolumn{2}{|c|}{ Mentioned } & \multicolumn{2}{|c|}{ Total } \\
\hline & \multicolumn{6}{|c|}{$\begin{array}{l}\text { No statistics are computed because } \\
\text { ASSUROR and ISAE } 3000 \text { are constants. }\end{array}$} & \multicolumn{6}{|c|}{$\begin{array}{l}\text { Pearson chi-square }=22.250(\mathrm{p}=0.000) \\
\text { Fisher's exact test }(\mathrm{p}=0.006 ; 0.006)\end{array}$} \\
\hline AA1000AS & \multicolumn{2}{|c|}{ No } & \multicolumn{2}{|c|}{ Yes } & \multicolumn{2}{|c|}{ Total } & \multicolumn{2}{|c|}{ No } & \multicolumn{2}{|c|}{ Yes } & \multicolumn{2}{|c|}{ Total } \\
\hline Assuror & $\mathrm{n}$ & $\%$ & $\mathrm{n}$ & $\%$ & $\mathrm{n}$ & $\%$ & $\mathrm{n}$ & $\%$ & $\mathrm{n}$ & $\%$ & $\mathrm{n}$ & $\%$ \\
\hline Non-accountant & 0 & 0.0 & 0 & 0.0 & 0 & 0.0 & 7 & 100.0 & 0 & 0.0 & 7 & 100.0 \\
\hline Accountant & 24 & 64.9 & 13 & 35.1 & 37 & 100.0 & 67 & 88.2 & 9 & 11.8 & 76 & 100.0 \\
\hline \multirow[t]{2}{*}{ Total } & 24 & 64.9 & 13 & 35.1 & 37 & 100.0 & 74 & 89.2 & 9 & 10.8 & 83 & 100.0 \\
\hline & \multicolumn{6}{|c|}{$\begin{array}{c}\text { No statistics are computed because } \\
\text { ASSUROR is a constant. }\end{array}$} & \multicolumn{6}{|c|}{$\begin{array}{l}\text { Pearson chi-square }=0.930(\mathrm{p}=0.335) \\
\text { Fisher's exact test }(\mathrm{p}=1.000 ; 0.433)\end{array}$} \\
\hline
\end{tabular}

With regard to the level of assurance provided, analysis of the results obtained (detailed in Table 11) revealed no association between the entry into force of the Act and any reference to the level of assurance provided ( $p>0.10)$. In both periods, most assurors referred to the level applied. Neither was the level itself associated with the Act's implementation ( $p>0.10)$, with most assurors certifying a limited/moderate level of assurance in both periods.

Table 11. Chi-square test: Level of assurance by period

\begin{tabular}{|c|c|c|c|c|c|c|c|}
\hline \multicolumn{8}{|c|}{ Level of assurance } \\
\hline & \multicolumn{3}{|c|}{ Not mentioned } & \multicolumn{2}{|c|}{ Mentioned } & \multicolumn{2}{|c|}{ Total } \\
\hline Period & & $\mathrm{n}$ & $\%$ & $\mathbf{n}$ & $\%$ & $\mathbf{n}$ & $\%$ \\
\hline Before Act $11 / 2018$ & 3 & & 7.5 & 37 & 92.5 & 40 & 100.0 \\
\hline After Act $11 / 2018$ & 2 & & 2.4 & 83 & 97.6 & 85 & 100.0 \\
\hline Total & 5 & & 4.0 & 120 & 96.0 & 125 & 100.0 \\
\hline
\end{tabular}

Pearson chi-square $=1.877(\mathrm{p}=0.171)$

Fisher's exact test $(\mathrm{p}=0.326 ; 0.186)$

\begin{tabular}{lllllll}
\hline & \multicolumn{2}{l}{ Limited/Moderate } & \multicolumn{2}{l}{$\begin{array}{l}\text { Reasonable/High } \\
\text { Combination }\end{array}$} & or & \multicolumn{2}{c}{ Total } \\
\hline Period & $\mathbf{n}$ & $\%$ & $\mathbf{n}$ & \% & n & $\%$ \\
\hline Before Act $11 / 2018$ & 34 & 91.9 & 3 & 8.1 & 37 & 100.0 \\
After Act $11 / 2018$ & 79 & 95.2 & 4 & 4.8 & 83 & 100.0 \\
Total & 113 & 94.2 & 7 & 5.8 & 120 & 100.0 \\
\hline
\end{tabular}

Pearson chi-square $=0.504(\mathrm{p}=0.478)$

Fisher's exact test $(\mathrm{p}=0.675 ; 0.370)$

The results obtained for the level of assurance by type of assuror (Table 12), show that only accountants declared this level before the Act's entry into force, 
and that most of them $(91.9 \%)$ applied a limited/moderate level. Subsequently, all of the accountant firms mentioned the level of assurance, whereas the nonaccountants did so in only $77.8 \%$ of cases. The application of a limited/moderate level was almost universal among the accountants (96.1\%), whereas the application of a reasonable/high level or a combination of both levels was more frequent among the non-accountants (14.3\%). In both periods, the likelihood of the level of assurance being mentioned was significantly associated with the type of assuror ( $\mathrm{p}<0.01$ ), with accountants being more likely to mention the level. However, the level of assurance was not significantly associated with the type of assuror $(\mathrm{p}>0.10)$.

Table 12. Chi-square test: Level of assurance by type of assuror

\begin{tabular}{|c|c|c|c|c|c|c|c|c|c|c|c|c|}
\hline \multicolumn{13}{|c|}{ Level of assurance } \\
\hline \multirow[b]{3}{*}{ Assuror } & \multicolumn{6}{|c|}{ Before the Act } & \multicolumn{6}{|c|}{ After the Act } \\
\hline & \multicolumn{2}{|c|}{$\begin{array}{c}\text { Not } \\
\text { mentioned }\end{array}$} & \multicolumn{2}{|c|}{ Mentioned } & \multicolumn{2}{|c|}{ Total } & \multicolumn{2}{|c|}{$\begin{array}{c}\text { Not } \\
\text { mentioned }\end{array}$} & \multicolumn{2}{|c|}{ Mentioned } & \multicolumn{2}{|c|}{ Total } \\
\hline & $\mathbf{n}$ & $\%$ & $\mathrm{n}$ & $\%$ & n & $\%$ & $\mathbf{n}$ & $\%$ & $\mathbf{n}$ & $\%$ & $\mathbf{n}$ & $\%$ \\
\hline Non-accountant & 3 & 100.0 & 0 & 0.00 & 3 & 100.0 & 2 & 22.2 & 7 & 77.8 & 9 & 100.0 \\
\hline Accountant & 0 & 0.0 & 37 & 100.0 & 37 & 100.0 & 0 & 0.0 & 76 & 100.0 & 76 & 100.0 \\
\hline \multirow[t]{3}{*}{ Total } & 3 & 7.5 & 37 & 92.5 & 40 & 100.0 & 2 & 2.4 & 83 & 97.6 & 85 & 100.0 \\
\hline & \multicolumn{6}{|c|}{$\begin{array}{l}\text { Pearson chi-square }=40.000(\mathrm{p}=0.000) \\
\text { Fisher's exact test }(\mathrm{p}=0.000 ; 0.000)\end{array}$} & \multicolumn{6}{|c|}{$\begin{array}{l}\text { Pearson chi-square }=17.296(\mathrm{p}=0.000) \\
\text { Fisher's exact test }(\mathrm{p}=0.010 ; 0.010)\end{array}$} \\
\hline & \multicolumn{2}{|c|}{$\begin{array}{l}\text { Limited/ } \\
\text { Moderate }\end{array}$} & \multicolumn{2}{|c|}{$\begin{array}{c}\text { Reasonable/ } \\
\text { High or } \\
\text { Combination }\end{array}$} & \multicolumn{2}{|c|}{ Total } & \multicolumn{2}{|c|}{$\begin{array}{l}\text { Limited/ } \\
\text { Moderate }\end{array}$} & \multicolumn{2}{|c|}{$\begin{array}{c}\text { Reasonable/ } \\
\text { High or } \\
\text { Combination }\end{array}$} & \multicolumn{2}{|c|}{ Total } \\
\hline Assuror & $\mathrm{n}$ & $\%$ & $\mathrm{n}$ & $\%$ & $\mathrm{n}$ & $\%$ & $\mathrm{n}$ & $\%$ & $\mathrm{n}$ & $\%$ & $\mathrm{n}$ & $\%$ \\
\hline Non-accountant & 0 & 0.0 & 0 & 0.0 & 0 & 0.0 & 6 & 85.7 & 1 & 14.3 & 7 & 100.0 \\
\hline Accountant & 34 & 91.9 & 3 & 8.1 & 37 & 100.0 & 73 & 96.1 & 3 & 3.9 & 76 & 100.0 \\
\hline \multirow[t]{2}{*}{ Total } & 34 & 91.9 & 3 & 8.1 & 37 & 100.0 & 79 & 95.2 & 4 & 4.8 & 83 & 100.0 \\
\hline & \multicolumn{6}{|c|}{$\begin{array}{l}\text { No statistics are computed because } \\
\text { ASSUROR is a constant. }\end{array}$} & \multicolumn{6}{|c|}{$\begin{array}{l}\text { Pearson chi-square }=1.493(\mathrm{p}=0.222) \\
\text { Fisher's exact test }(\mathrm{p}=0.302 ; 0.302)\end{array}$} \\
\hline
\end{tabular}

Table 13 refers to the kinds of conclusions presented in the assurance report. The Act's entry into force was found to be significantly associated with the type of conclusions $(\mathrm{p}<0.01)$. Although most assurors issued unmodified conclusions, $14.1 \%$ issued modified conclusions after the Act came into force. 
Assurance on non-financial information in Spain

Table 13. Chi-square test: Conclusions by period

\begin{tabular}{lccccccc}
\hline & \multicolumn{3}{c}{ Conclusions } & & & \\
\hline & \multicolumn{2}{c}{ Unmodified } & \multicolumn{2}{c}{ Modified } & \multicolumn{2}{c}{ Total } \\
\hline \multicolumn{1}{c}{ Period } & $\mathbf{n}$ & $\%$ & $\mathbf{n}$ & $\%$ & $\mathbf{n}$ & $\%$ \\
\hline Before Act 11/2018 & 40 & 100.0 & 0 & 0.0 & 40 & 100.0 \\
After Act 11/2018 & 73 & 85.9 & 12 & 14.1 & 85 & 100.0 \\
Total & 113 & 90.4 & 12 & 9.6 & 125 & 100.0 \\
\hline
\end{tabular}

Pearson chi-square $=6.247(\mathrm{p}=0.012)$

Fisher's exact test $(\mathrm{p}=0.009 ; 0.007)$

Our analysis of the conclusions presented according to the type of assuror (Table 14) shows that all assurors issued unmodified conclusions before the Act came into force. Afterwards, the non-accountants continued to issue unmodified conclusions, but only $84.2 \%$ of the accountants did so, while $15.8 \%$ issued modified conclusions. Nevertheless, the type of conclusion issued was not significantly associated with the type of assuror $(p>0.10)$.

Table 14. Chi-square test: Conclusions by type of assuror

\begin{tabular}{lcccccccccccc}
\hline & \multicolumn{11}{c}{ Conclusions } \\
\hline & Unmodified & Modified & Total & Unmodified & Modified & Total \\
\hline \multicolumn{1}{c}{ Assuror } & $\mathbf{N}$ & $\%$ & $\mathbf{n}$ & $\%$ & $\mathbf{n}$ & $\%$ & $\mathbf{n}$ & $\%$ & $\mathbf{n}$ & $\%$ & $\mathbf{n}$ & $\%$ \\
\hline Non-accountant & 3 & 100.0 & 0 & 0.0 & 3 & 100.0 & 9 & 100.0 & 0 & 0.00 & 9 & 100.0 \\
Accountant & 37 & 100.0 & 0 & 0.0 & 37 & 100.0 & 64 & 84.2 & 12 & 15.8 & 76 & 100.0 \\
Total & 40 & 100.0 & 0 & 0.0 & 40 & 100.0 & 73 & 85.9 & 12 & 14.1 & 85 & 100.0 \\
\hline & No statistics are computed because & Pearson chi-square $=1.655(\mathrm{p}=0.198)$ \\
& CONCLUSIONS is a constant. & \multicolumn{1}{c}{ Fisher's exact test $(\mathrm{p}=0.347 ; 0.236)$} \\
\hline
\end{tabular}

Table 15 shows the results obtained with respect to the recommendations made. Notably, the entry into force of the Act is significantly associated with the assuror making recommendations to the reporting organisation $(\mathrm{p}<0.05)$. Specifically, the likelihood of this taking place rose from $15.3 \%$ to $32.5 \%$ with the entry into force of Act 11/2018.

Table 15. Chi-square test: Recommendations by period

\begin{tabular}{lcrrrrr}
\hline \multicolumn{7}{c}{ Recommendations } \\
\hline \multicolumn{1}{c}{ Period } & \multicolumn{3}{c}{ No } & \multicolumn{2}{c}{ Yes } & \multicolumn{2}{c}{ Total } \\
\hline Before Act 11/2018 & $\mathbf{n}$ & $\%$ & n & $\%$ & n & $\%$ \\
After Act 11/2018 & 27 & 67.5 & 13 & 32.5 & 40 & 100.0 \\
Total & 72 & 84.7 & 13 & 15.3 & 85 & 100.0 \\
Pearson chi-square $=4.888(\mathrm{p}=0.027)$ & 99 & 79.2 & 26 & 20.8 & 125 & 100.0 \\
\hline
\end{tabular}


Finally, concerning the recommendations made according to the type of assuror (Table 16), only the accountants made recommendations (35.1\% doing so before the Act's entry into force and $17.1 \%$ afterwards). Nevertheless, the presentation of recommendations was not significantly associated with the type of assuror $(\mathrm{p}>0.10)$.

Table 16. Chi-square test: Recommendations by type of assuror

\begin{tabular}{|c|c|c|c|c|c|c|c|c|c|c|c|c|}
\hline \multicolumn{13}{|c|}{ Recommendations } \\
\hline \multirow[b]{3}{*}{ Assuror } & \multicolumn{6}{|c|}{ Before the Act } & \multicolumn{6}{|c|}{ After the Act } \\
\hline & \multicolumn{2}{|c|}{ No } & \multicolumn{2}{|c|}{ Yes } & \multicolumn{2}{|c|}{ Total } & \multicolumn{2}{|c|}{ No } & \multicolumn{2}{|c|}{ Yes } & \multicolumn{2}{|c|}{ Total } \\
\hline & $\mathbf{N}$ & $\%$ & $n$ & $\%$ & $n$ & $\%$ & $\mathrm{n}$ & $\%$ & $n$ & $\%$ & $\mathrm{n}$ & $\%$ \\
\hline Non-accountant & 3 & 100.0 & 0 & 0.0 & 3 & 0.0 & 9 & 100.0 & 0 & 0.00 & 9 & 100.0 \\
\hline Accountant & 24 & 64.9 & 13 & 35.1 & 37 & 100.0 & 63 & 82.9 & 13 & 17.1 & 76 & 100.0 \\
\hline \multirow[t]{2}{*}{ Total } & 27 & 67.5 & 13 & 32.5 & 40 & 100.0 & 72 & 84.7 & 13 & 15.3 & 85 & 100.0 \\
\hline & $\begin{array}{l}\text { Pear } \\
\text { Fish }\end{array}$ & $\begin{array}{l}\text { son chi } \\
\text { er's exa }\end{array}$ & $\begin{array}{l}\text { squa } \\
\text { ct tes }\end{array}$ & $\begin{array}{l}e=1.5 \\
t(p=c\end{array}$ & $\begin{array}{l}5621 \\
.538\end{array}$ & $\begin{array}{l}=0.211) \\
0.296)\end{array}$ & $\begin{array}{l}\text { Pear } \\
\text { Fish }\end{array}$ & $\begin{array}{l}\text { son chi- } \\
\text { er's exac }\end{array}$ & qua & $\begin{array}{l}=1.81 \\
(p=0 .\end{array}$ & $\begin{array}{l}7(\mathrm{p} \\
343 ;\end{array}$ & $\begin{array}{l}=0.178 \\
.207)\end{array}$ \\
\hline
\end{tabular}

\section{Discussion and conclusions}

In this paper, we analyse the situation, in the Spanish context, of the mandatory external assurance of companies' non-financial statements. In our opinion, this study is both timely and important. Moreover, its significance was heightened by the entry into force of Act $11 / 2018$, as the study periods analysed enabled us to highlight the effects of the transition from voluntary to mandatory external assurance.

The results obtained show that some Spanish listed companies are still not adopting external assurance despite this being mandatory since the Act's entry into force. However, it should be noted that some of the companies that do not assure their reports are not in fact obliged to do so because they have fewer than 250 employees. Nevertheless, they might choose to do so as a means of legitimating corporate behaviour.

Our analysis revealed no significant association between the choice of assuror and the Act's implementation. Regardless of the period considered, most companies prefer accountants to perform the assurance process. On the other hand, the type of assuror preferred does depend on certain corporate characteristics. Specifically, companies listed in the IBEX-35 are more likely to choose one of the Big 4 firms to assure their reports. In particular, companies that made a financial loss during the previous year preferred the firm EY, those operating in a non-sensitive business sector opted for KPMG, and those which had a sustainability committee and a longer-serving CEO were more inclined towards PwC. 
The study results also show that the entry into force of the Act significantly affected the use of applicable standards. Thus, AA1000AS was more commonly used before the Act came into force than afterwards. This inversion might have taken place because this standard is oriented towards sustainability reports, whereas the ISAE 3000 focuses more on non-financial information. On the other hand, the combined use of both standards was more common after the application of the Act.

We also found differences according to the type of assuror hired for this task. In line with Deegan et al. (2006a, b), we found that accountant firms were more likely to mention the standard(s) used. Moreover, and confirming Mock et al. $(2007,2013)$, we observed that accountants were more likely to use ISAE 3000 , which in itself is not surprising, since this standard is issued by an international auditing body (Perego and Kolk, 2012). Following Manetti and Toccafondi (2012), we found that accountants were more likely to combine the two standards in their assurance process. The use of external standards is consistent with the institutional theory approach of normative isomorphism (Smith et al., 2011; Fernández-Feijóo et al., 2015).

Confirming the prior work of O'Dwyer and Owen (2005) and Bollas-Araya et al. (2018), we show that accountants are more likely to indicate the level of assurance. However, we did not measure a significant association between the level of assurance stated and the type of assuror responsible.

The entry into force of Act 11/2018 was also relevant to the assurors' stated conclusions, which were more likely to be modified after the Act's implementation. This might be because mandatory NFI reporting is relatively recent, and therefore companies might not yet be sufficiently prepared to fully comply with its requirements. On the other hand, we found no significant differences by type of assuror.

Our results also indicate that implementation of the Act influenced the recommendations made, but in a negative sense, as the assurors actually made more recommendations before the Act's entry into force. However, these recommendations were not significantly associated with the type of assuror.

The research presented in this paper is subject to some limitations, such as the use of just two time points, spanning twelve months. The data from a longer period could usefully be analysed, to generalise the results obtained. Moreover, in the future, we hope to expand the scope of our analysis to include companies in other EU countries.

Nevertheless, our analysis has significant implications. For academics, it enhances our understanding of how companies react to the imposition of a mandatory system of external assurance, as recently occurred in Spain. From a managerial perspective, the external assurance of NFI is an opportunity to demonstrate the company's commitment to sustainability and to enhance its 
accountability to stakeholders. Nevertheless, companies should be cautious, taking care to employ assurance providers offering professionalism and integrity. Similarly, assurance providers should act in accordance with strict ethical principles in order to avoid situations such as the financial scandals that have affected some members of the audit profession. Therefore, the assurors' independence needs to be clarified. Finally, stakeholders should be made more aware that the assurance of non-financial corporate reporting improves its quality and reliability.

\section{References}

AccountAbility (2008a). AA1000 Assurance Standard 2008. London: AccountAbility. AccountAbility (2008b). AA1000 Principles Standard 2008. London: AccountAbility.

Adams, C.A., \& Narayanan, V. (2007). The 'standardization' of sustainability reporting. In Sustainability, Accounting and Accountability; Unerman, J., Bebbington, J., O'Dwyer, B., Eds.; Routledge: London, UK; New York, NY, USA; pp. 70-85.

Aureli, S.; Salvatori, F.; \& Magnaghi, E. (2020). A country-comparative analysis of the transposition of the EU Non-Financial Directive: an institutional approach. Accounting, Economics, and Law, https://doi.org/10.1515/ael-2018-0047.

Bollas-Araya, H.M., Polo-Garrido, F., \& Seguí-Mas, E. (2019). Determinants of CSR reporting and assurance: an analysis of top cooperative and mutual organisations. Australian Accounting Review, 29 (4), 692-707.

Chandler, A.D. (1990). Strategy and structure: chapter in the history of the industrial enterprise, Cambridge, the Mitt Press

Deegan, C. (2002). Introduction. The legitimising effect of social and environmental disclosures-a theoretical foundation. Accounting, Auditing and Accountability Journal, 15 (3), 282-311.

Deegan, C., Cooper, B.J., \& Shelly, M. (2006a). An investigation of TBL report assurance statements: Australian evidence. Australian Accounting Review, 16, 2-18.

Deegan, C., Cooper, B. J., \& Shelly, M. (2006b). An investigation of TBL report assurance statements: UK and European evidence. Managerial Auditing Journal, 21(4), 329-371.

DiMaggio, P.J., \& Powell, W.W. (1983). The iron cage revisited: institutional isomorphism and collective rationality in organizational fields. American Sociological Review, 48, 147-160.

EU (2014a). Directive 2014/95/EU of the European Parliament and of the Council of 22 October 2014 amending Directive 2013/34/EU as regards disclosure of non-financial and diversity information by certain large undertakings and groups Text with EEA relevance.

Fernández-Feijóo-Souto, B., Romero, S., \& Ruiz-Blanco, S. (2012). Measuring quality of sustainability reports and assurance statements: Characteristics of the high-quality reporting companies. International Journal of Social System Sciences, 4, 5-27.

Fernández-Feijóo-Souto, B., Romero, S., \& Ruiz-Blanco, S. (2015). Multilevel approach to sustainability report assurance decisions. Australian Accounting Review, 25, 346-358. 
Assurance on non-financial information in Spain

Ferreira Gomes, S., Pereira, T.C., \& Castelo Branco, E.M. (2015). Sustainability reporting and assurance in Portugal. Corporate Governance, 15, 281-292.

Fonseca, A. (2010). How credible are mining corporations' sustainability reports? A critical analysis of external assurance under the requirements of the international council on mining and metal. Corporate Social Responsibility and Environmental Management, 17 (6), 355-370.

Finkelstein, S., Hambrick, D.C., \& Cannella, A.A. (2009). Strategic Leadership: Theory and Research on Executives, Top Management Teams, and Boards. Oxford University Press: New York

García-Sánchez, I.M., Rodriguez-Dominguez, L., \& Gallego-Álvarez, I. (2011). Corporate governance and strategic information on the internet. Accounting, Auditing and Accountability Journal, 24(4), 471-501. https://doi.org/10.1108/09513571111133063

Garrido-Miralles, P., Zorio, A., \& García-Benau, M.A. (2016). Sustainable development, stakeholder engagement and analyst forecasts' accuracy: positive evidence from the Spanish setting. Sustainable Development, 24(2). https://doi.org/10.1002/sd.1607

GRI (2013). The External Assurance of Sustainability Reporting; Research \& Development Series. GRI: Amsterdam, the Netherlands.

Hernández, J. (2017). Pocas novedades en la transposición de la Directiva de Información no financiera. Blog KPMG Responsabilidad empresarial. Available at http://www. kpmgresponsabilidadempresarial.es/pocas-novedades-en-la-transposicion-de-ladirectiva-de-informacion-no-financiera/

IAASB (2013). ISAE 3000 (Revised), Assurance Engagements Other Than Audits or Reviews of Historical Financial Information. International Federation of Accountants: New York, NY, USA.

KPMG (2011). KPMG international survey of corporate responsibility reporting 2011. London: KPMG.

KPMG (2015). The KPMG Survey of Corporate Responsibility Reporting 2015. London: KPMG.

KPMG (2017). The KPMG Corporate Responsibility Reporting 2017. London: KPMG.

Lewis, B.W., Walls, J.L., \& Dowell, G.W.S. (2014). Difference in degrees: CEO characteristics and firm environmental disclosure. Strategic Management Journal, 35(5), 712-722.

Manes-Rossi, F., Tiron-Tudor, A., Nicolò, G., \& Zanellato, G. (2018). Ensuring more sustainable reporting in europe using non-financial disclosure - de facto and de jure evidence. Sustainability, 10(4), 1162.

Manetti, G., \& Becatti, L. (2009). Assurance services for sustainability reports: Standards and empirical evidence. Journal of Business Ethics, 87, 289-298.

Manetti, G., \& Toccafondi, S. (2012). The role of stakeholders in sustainability reporting assurance. Journal of Business Ethics, 107, 363-377.

Martínez-Ferrero, J., \& García-Sánchez, I. M. (2018). The level of sustainability assurance: The effects of brand reputation and industry specialisation of assurance providers. Journal of Business Ethics, 150(4), 971-990.

Matuszak, L., \& Rozanska, E. (2017). CSR disclosure in Polish-listed companies in the light of Directive 2014/95/EU requirements: Empirical evidence. Sustainability, 9, 2304.

Mion, G. \& Loza-Adaui, C.R. (2019). Mandatory nonfinancial disclosure and its consequences on the sustainability reporting quality of Italian and German companies. Sustainability, 11,4612 . 
Mock, T. J., Strohm, C., \& Swartz, K. M. (2007). An examination of worldwide assured sustainability reporting. Australian Accounting Review, 17(41), 67-77.

Mock, T.J., Rao, S.S., \& Srivastava, R.P. (2013). The development of worldwide sustainability reporting assurance. Australian Accounting Review, 23(4), 280-294.

O’Dwyer, B., \& Owen, D. (2005). Assurance statement practice in environmental, social and sustainability reporting: a critical evaluation. The British Accounting Review, 14, 205-229.

O’Dwyer, B., Owen, D., \& Unerman, J. (2011). Seeking legitimacy for new assurance forms: The case of assurance on sustainability reporting. Accounting, Organizations and Society, 36, 31-52.

Ortiz, E., \& Marín, S. (2017). Comunicar información no financiera e IDE por regiones. Revista de Globalización, Competitividad y Gobernabilidad, 11(1), 94-111.

Perego, P., \& Kolk, A. (2012). Multinationals' accountability on sustainability: the evolution of third-party assurance of sustainability reports. Journal of Business Ethics, 110, 173-190.

Romero, S., Ruiz, S., and Fernández-Feijóo, B. (2010). Assurance statement for sustainability reports: the case of Spain. Proceedings of the Northeast Business \& Economics Association, San Diego: 105-112.

Seguí-Mas, E., Polo-Garrido, F., \& Bollas-Araya, H.M. (2018). Sustainability assurance in socially-sensitive sectors: a worldwide analysis of the financial services industry. Sustainability, 10, 2777.

Sierra-García, L., García-Benau, M.A., \& Bollas-Araya, H.M. (2018). Empirical analysis of non-financial reporting by Spanish companies. Administrative Sciences, 8(3), 29-40.

Smith, J., Haniffa, R., \& Fairbrass, J.A. (2011). Conceptual framework for investigating 'capture' in corporate sustainability reporting assurance. Journal of Business Ethics, 99, 425-439.

Tarquinio, L., Raucci, D., \& Benedetti, R. (2018). An investigation of global reporting initiative performance indicators in corporate sustainability reports: Greek, Italian and Spanish evidence. Sustainability, 10(4), 897-915.

Tiron-Tudor, A., Nistor, C.S., Ştefănescu, C.A., \& Zanellato, G. (2019). Encompassing nonfinancial reporting in a coercitive framework for enhancing social responsibility: Romanian listed companies' case. Amfiteatru Economic, 21(52), 2-16.

Velte, P., \& Stawinoga, W. (2017). Empirical research on corporate social responsibility assurance (CSRA): A literature review. Journal of Business Economics, 87(8), 1017-1066.

Venturelli, A., \& Pizzi, S. (2020). What Drives The Level Of Non-Financial Assurance In PIEs? Empirical evidence on the European firms listed on Forbes 2000. In Accounting, Accountability and Society: Trends and Perspectives in Reporting, Management and Governance for Sustainability, 245-265. Springer: Cham.

Venturelli, A., Simona Costa, F.C., Leopizzi, R., \& Pizzi, S. (2017). Directive 2014/95/EU: Are Italian companies already compliant? Sustainability, 9, 1385.

Zorio, A., García-Benau, M.A., \& Sierra, L. (2013). Sustainability development and the quality of assurance reports: empirical evidence. Business Strategy \& Environment, 22, 484-500.

Contaduría Universidad de Antioquia - No. 79. Medellín, julio-diciembre de 2021 